\title{
KEANEKARAGAMAN JENIS-JENIS IKAN DI SUNGAI TEMBESI KECAMATAN BATHIN VIII KABUPATEN SAROLANGUN PROVINSI JAMBI
}

\author{
Muhammad $^{1 *}$ Syafrialdi $^{2}$ Rini Hertati $^{2}$ \\ ${ }^{1}$ Mahasiswa Jurusan Pemanfaatan Sumberdaya Perikanan Fakultas Perikanan, \\ Universitas Muara Bungo - Jambi \\ ${ }^{2}$ Staf Pengajar Jurusan Pemanfaatan Sumberdaya Perikanan Fakultas Perikanan, \\ Universitas Muara Bungo-Jambi \\ *Email: syafrialdi_umb@ymail.com
}

\begin{abstract}
ABSTRAK
Salah Satu Sungai yang terdapat di Kabupaten Sarolangun yaitu Sungai tembesi. Sungai ini merupakan sumber daya alam yang memliki potensi ikan yang besar dan ekologi sebagai media bagi organisme aquatik.. Penelitian ini bertujuan untuk mengetahui jenis-jenis ikan yang tertangkap, indeks keanekaragaman jenis ikan, kepadatan populasi, kepadatan relatif dan frekuensi kehadiran di Sungai tembesi. Hasil penelitian menunjukan bahwa jenis ikan yang terdapat di Sungai tembesi terdiri dari jenis ikan baung (Mystus nemurus), dalum (Bagarius yarelli), lais (Criptopterus limpok), belang muju (Ostechilus haselti), simancung (Schismatorhichus heterorhynchus), lampam (B.schwanenfeldi), semuruk (Osteochilus melanopleura), kebarau (Hampala macrolepidato), seluang (Rasbora argyrotaenia). Indeks keanekaragaman tertinggi di jumpai di Stasiun III Dusun Dalam dengan indeks 2.18 dan terendah terdapat pada Stasiun I di Dusun Limbur Tembesi dengan indeks 2.01. Nilai indeks dominansi (D) tertinggi pada stasiun 1 yaitu 0.14 dan terendah terdapat pada stasiun III dengan nilai 0.11 . Nilai indeks keseragaman (E) tertinggi terdapat pada stasiun III dengan nilai 1.05 dan terendah pada stasiun I 0.96. Kepadatan Populasi (KP) tertinggi ditemukan pada jenis ikan seluang (Rasbora argyrotaenia), dalum (Bagarius yarelli), lampam (B.schwanenfeldi), lais (Criptopterus limpok) dan belang muju (Ostechilus haselti). Kepadatan Relatif (KR) tertinggi terdapat pada ikan seluang (Rasbora argyrotaenia) dan terendah pada ikan kebarau (Hampala macrolepidato). Frekuensi Kehadiran (FK\%) jenis ikan di Sungai tembesi Kabupaten Sarolangun Propinsi Jambi dapat dikatakan dengan kehadiran sedang yaitu $77.77 \%$.
\end{abstract}

Kata Kunci: Keanekaragaman, Jenis Ikan, Sungai Tembesi, Sarolangun

\section{PENDAHULUAN}

\section{Latar Belakang}

Salah Satu Sungai yang terdapat di Kabupaten Sarolangun yaitu Sungai tembesi. Sungai ini merupakan sumber daya alam yang memliki potensi ikan yang besar dan ekologi sebagai media bagi organisme aquatik. Ikan merupakan salah satu jenis penghuni perairan yang rentan terhadap perubahan lingkungan. Baik itu oleh kegiatan 
manusia maupun perubahan yang terjadi karena pengaruh bencana alam. Pola pertumbuhan jenis ikan di suatu perairan akan dipengaruhi oleh parameter lingkungan seperti kondisi suhu, oksigen terlarut dan faktor lainnya. Bila kondisi parameter-parameter tersebut optimal, ikan akan mengalami pola pertumbuhan yang ideal. Sungai tembesi merupakan sumber kehidupan bagi masyarakat sekitar nya umum nya di gunakan untuk memenuhi kehidupan sehari- hari seperti mencuci dan lainnya. Berdasarkan informasi yang di dapatkan dari masyarakat bahwa hasil penangkapan ikan di Sungai tembesi Kecamatan Bathin VIII Kabupaten Sarolangun semakin menurun dari tahun-ketahun. Hal ini di karenakan habitat ikan tersebut terganggu oleh aktivitas manusia.

Maka dari itu dengan adanya perubahan kegiatan manusia akan

\section{METODE PENELITIAN}

\section{Waktu dan Tempat}

Penelitian ini dilakukan pada bulan Juni sampai dengan Juli 2019 mengakibatkan perubahan secara biologis, kimia dan fisika terhadap sungai. Akibat dari itu dampaknya akan memberi pengaruh terhadap keanekaragaman jenis ikan di sungai. Indeks keanekaragaman merupakan suatu penilaian untuk mengetahui keanekaragaman yang berhubungan erat dengan spesies di dalam komunitas (Kotellat et al, 1993). Sudrajat et al., (2009), keberadaan jenis-jenis ikan yang ada di perairan sungai Tembesi belum di ketahui secara aktual. Penelitian ini akan mengkaji tentang keanekaragaman di perairan Sungai tembesi Kecamatan Bathin VIII Kabupaten Sarolangun. Tujuan dari penelitian ini adalah untuk mengetahui jenis-jenis ikan yang tertangkap, indeks keanekaragaman jenis ikan, kepadatan populasi, kepadatan relatif dan frekuensi kehadiran

di Sungai tembesi dengan 3 stasiun pengamatan (Gambar 1).

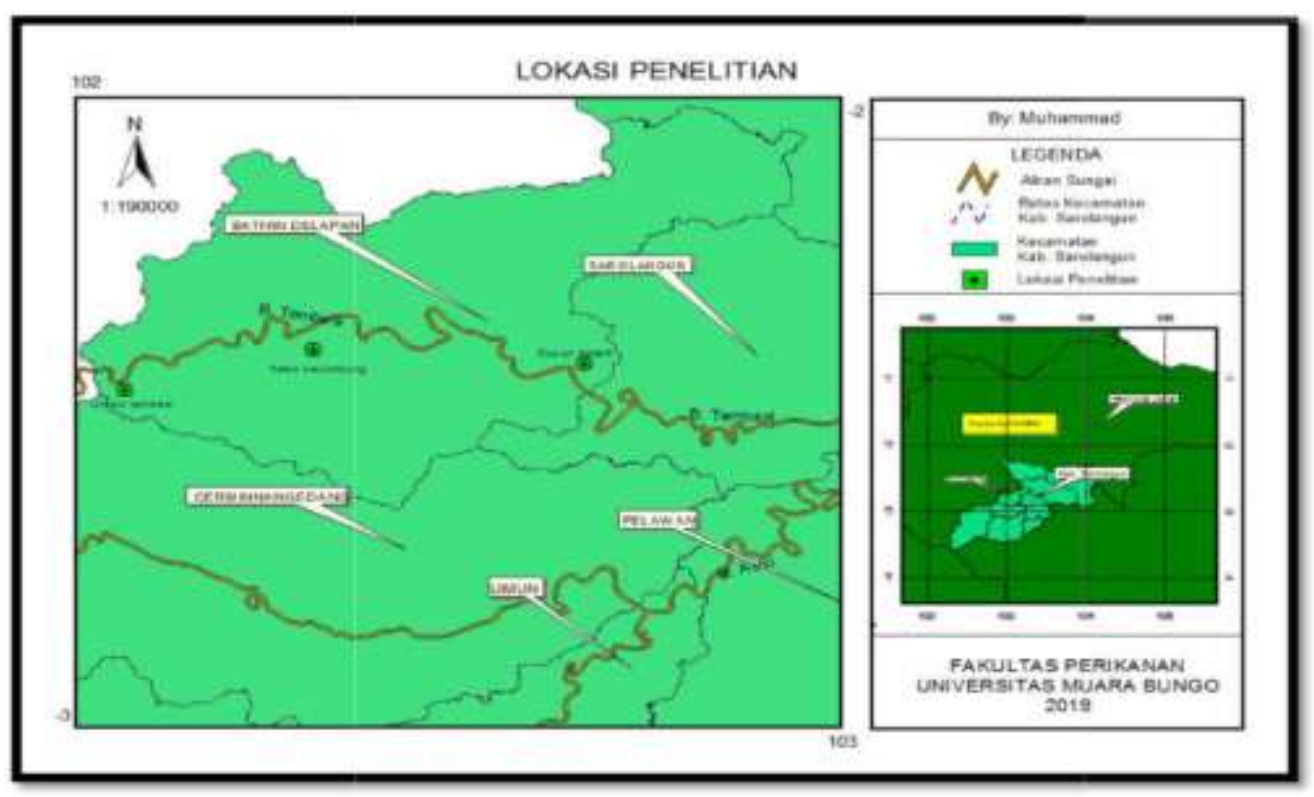

Gambar 1. Peta Lokasi penelitian 
Penentuan stasiun pengamatan melalui purposive sampling dengan merujuk hasil studi pendahuluan yaitu mewakili satu daerah aliran sungai utama yang menjadi tiga bagian yaitu: hulu (Stasiun I), tengah (Stasiun II) dan hilir (Stasiun III). Daerah hilir (Stasiun I) merupakan daerah terdekat dengan tempat yang sering digunakan masyarakat dalam memenuhi kebutuhan sehari-hari seperti: penangkapan ikan, mandi, cuci dan kakus. Stasiun I berada pada titik koordinat S $2^{0} 15^{\prime} 28.0512$ ", E $102^{0}$ 31'26.5764' dengan kedalaman 1-5 $\mathrm{m}$ dan panjang $100 \mathrm{~m}$ dengan lebar $60 \mathrm{~m}^{2}$. Memiiki karakteristik arus air cukup deras dan berbatu. Sedangkan daerah tengah (Stasiun II) merupakan tempat terjauh dari permukiman masyarakat dan terdapat aktivitas masyarakat seperti Penambangan Emas Tanpa Izin (PETI) dengan titik koordinat $\mathrm{S} 2^{0}$ $15^{\prime} 4108^{\prime \prime}$, E $102^{0} \quad 31^{\prime} 43.5144^{\prime \prime}$,

\section{Analisis Data}

1. Analisis Indeks Keanekaragaman Jenis Ikan (Hi)

Indeks keanekaragaman (H') merupakan gambaran kekayaan spesies ikan yang dapat dilihat dari kehadiran jumlah spesies dalam suatu komunitas dengan kelimpahan relatif (jumlah individu tiap spesies). Indeks keragaman yang paling umum digunakan adalah indeks menurut Shannon-Wiener (Brower \& Zar, 1990), dilambangkan dengan (H') yang dibatasi sebagai :

$$
H^{\prime}=-\sum_{\mathrm{i}=1}^{\mathrm{n}}(P i)\left(\log _{2} P i\right)
$$

Keterangan :

Dimana : memiliki kedalaman $1 \mathrm{~m}-6 \mathrm{~m}$ dan luas 100 x 60 m. Karakteristik perairan arus agak deras, berbatu dan berpasir. Stasiun III berada pada titik koordinat S $2^{0} 15^{\prime} 45.2988^{\prime \prime}$, E $102^{0} 33^{\prime} 3168^{\prime}$ " dengan karakteristik agak deras di hulu stasiun dan berarus tenang, kedalaman mencapai 1-5 m dengan panjang 100 dan lebar $60 \mathrm{~m}^{2}$.

\section{Alat dan Bahan}

Peralatan yang digunakan untuk penelitian ini yaitu: alat tulis, timbangan elektrik, untuk menangkap sampel ikan digunakan alat tangkap jaring, jala tebar, pancing/tajur, penggaris, kamera, GPS. Disamping itu untuk mengolah data diperlukan seperangkat (Personal Computer) atau PC. Sedangkan bahan yang diperlukan larutan formalin $4 \%$ dan es batu untuk menyimpan sampel agar tetap segar sampai kelokasi pengamatan.

H' = Indeks Keanekaragaman

(Shannon-Wienner).

$\mathrm{Pi}=$ Perbandingan antara

jumlah individu spesies ikan ke-i dengan jumlah total individu ikan (jumlah

individu spesies ke-i,Pi $=$ ni $/ \mathrm{N}$

ni = Jumlah individu jenis ke-i.

$\mathrm{N}=$ Jumlah total spesies.

Menurut Preniti et al., (2019) penentuan kriteria indeks keanekaragaman yaitu $\quad \mathrm{H}^{\prime}<1$ samadengan keanekaragaman rendah, jika $1<\mathrm{H}^{\prime}<3$ sama dengan keanekaragaman sedang dan jika $\mathrm{H}^{\prime}>3$ keanekaragaman tinggi.

2. Indeks Keseragaman (E)

Indeks (E ) individu tiap spesies yang terdapat pada suatu 
perairan dapat ditentukan dengan indeks keseragaman yaitu :

$$
E=\frac{H^{\prime}}{H^{l} \max }=\frac{H^{\prime}}{\log _{2} \mathrm{~s}}
$$

Keterangan :

$\mathrm{H}^{\prime}=$ Indeks Keanekaragaman

Shannon-Weiner

$\mathrm{H}^{\prime}$ max $=$ Keanekaragaman species maksimum

$\mathrm{E}=0$, terdapat dominasi Spesies atau semakin kecil keseragaman

$\mathrm{E}=1$, Jumlah Individu tiap spesies sama atau seragam

\section{Indeks Dominasi (D)}

Penentuan jenis ikan yang dominan didalam kawasan penelitian, ditentukan dengan menggunakan rumus berikut :

$$
D=\frac{n i}{N} \times 100 \%
$$

Keterangan :

$\mathrm{D}=$ Indeks dominansi suatu jenis ikan

$\mathrm{N}=$ jumlah individu suatu jenis

$\mathrm{N}=$ jumlah individu dari seluruh jenis

Kriteria :

$\mathrm{Di}=0-2 \%$ jenis tidak dominan

$\mathrm{D}=2-5 \%$ jenis sub dominan

$\mathrm{D}=>5 \%$ jenis dominan

\section{HASIL DAN PEMBAHASAN}

Selama penelitian dilakukan, ikan yg berhasil di kumpulkan berjumlah 138 ekor di tiga stasiun, terdiri dari 3 famili 8 genus 9 jenis ikan (Tabel 1). Menurut Fithra (2016) keanekaragaman dan kelimpahan ikan juga ditentukan oleh karakteristik habitat perairan.
4. Kepadatan Populasi, Kepadatan Relatif dan Frekuensi Kehadiran Menghitung

Kepadatan Populasi (KP), Kepadatan Relatif (KR) dan Frekuensi Kehadiran (FK) menggunakan persamaan sebagai berikut:

a. Kepadatan Populasi (KP)

$\mathrm{KP}\left(\right.$ indv $\left./ \mathrm{m}^{2}\right)=\underline{\text { Jumlah Individu }}$ Suatu jenis

Luas Area / Plot

b. Kepadatan Relatif (KR)

$$
\begin{aligned}
& \text { KR }(\%)=\frac{\text { Kepadatan Suatu }}{\mathrm{X}} \\
& \begin{array}{llll}
\text { Jenis } & X & 100 & \%
\end{array}
\end{aligned}
$$$$
\text { Seluruh Jenis }
$$

c. Frekuensi Kehadiran (FK)

$\mathrm{FK}=$ Jumlah Plot yang ditempati Suatu Jenis X 100 \%..................... Jumlah Total plot

Di mana:

FK $=0-25 \%:$ Kehadiran sangat jarang

FK $=25-50 \%:$ Kehadiran jarang

FK $=50-75 \%:$ Kehadiran sedang

FK $>75 \%$ : Kehadiran sering/absolut.

Karakteristik habitat di sungai sangat dipengaruhi kecepatan aliran sungai, kemiringan sungai, keberadaan hutan atau tumbuhan di sepanjang daerah aliran sungai yang berasosiasi dengan keberadaan hewan-hewan penghuninya. 
Tabel 1. Jenis-Jenis Ikan yang Tertangkap di Tiga Stasiun Sungai Tembesi Kecamatan Bathin VIII Kabupaten Sarolangun

\begin{tabular}{|c|c|c|c|c|}
\hline Famili & Genus & Spesies & $\begin{array}{c}\text { Nama } \\
\text { Daerah } \\
\end{array}$ & Jmlh (ekor) \\
\hline \multirow[t]{2}{*}{ Bagridae } & Macrones & Mystus nemurus & Baung & 11 \\
\hline & Macrones & Bagarius yarelli & Dalum & 21 \\
\hline Pangasidae & Cryptopterus & Criptopterus limpok (Blkr) & Lais & 17 \\
\hline \multirow[t]{6}{*}{ Cyprinidae } & $\begin{array}{l}\text { Ostechilus } \\
\text { Schismatorhync } \\
\text { hus }\end{array}$ & $\begin{array}{c}\text { Ostechilus hasselti } \\
\text { Schismatorhynchus } \\
\text { heterorhynchus }\end{array}$ & $\begin{array}{c}\text { Belang } \\
\text { muju } \\
\text { Simancung }\end{array}$ & $\begin{array}{l}15 \\
11\end{array}$ \\
\hline & Puntius & B.schwanenfeldi & Lampam & 18 \\
\hline & Osteochilus & $\begin{array}{c}\text { Osteochilus } \\
\text { melanopleura }\end{array}$ & Semuruk & 13 \\
\hline & Hampala & $\begin{array}{c}\text { Hampala } \\
\text { macrolepidota }\end{array}$ & Kebarau & 9 \\
\hline & Rasbora & $\begin{array}{c}\text { Rasbora } \\
\text { argyrotaenia }\end{array}$ & Seluang & 23 \\
\hline & & tal individu & & 138 \\
\hline
\end{tabular}

Jenis ikan yang terbanyak tertangkap di sepanjang perairan Sungai tembesi Kecamatan Bathin VIII Kabupaten Sarolangun yaitu dari famili cyprinidae. Jenis ikan famili cyprinidae ini mendominasi di setiap stasiun, individu golongan ikan yang tertangkap terbanyak dari famili ini yaitu ikan mas. Secara umum famili ini disebut keluarga ikan mas, kadang juga di sebut keluarga cyprinidae karena jenis cyprinidae habitat hidupnya tidak terlalu deras dan hidup di perairan dangkal dan terdapat banyak tumbuhan-tumbuhan air.

Hal ini sependapat dengan Erika (2018) bahwa Sungai lenggang lebih banyak didominansi oleh famili cyprinidae. Muslih (2014) menambahkan bahwa ikan perairan tawar di Asia tropika didominasi oleh famili cyprinidae dan siluridae sebagian besar dari jenis ikan yang ditemukan di sungai dan memiliki nilai ekonomis bagi masyarakat setempat.

$$
\text { Menurut Odum }
$$
lingkungan yang stabil dicirikan oleh kondisi yang seimbang dan mengandung kehidupan yang beranekaragam. Keanekaragaman jenis $\left(\mathrm{H}^{\prime}\right)$ dan keseragaman (E) merupakan indeks yang sering digunakan untuk mengevaluasi keadaan suatu lingkungan perairan berdasarkan kondisi biologi. Ekosistem yang baik mempunyai ciri-ciri keanekaragaman jenis yang tinggi dan penyebaran jenis individu yang hampir merata di setiap perairan. Perairan yang tercemar pada umumnya kekayaan jenis relatif rendah (Krebs, 1972). Lebih jelas keanekaragaman jenis ikan di sungai tembesi setiap stasiun dapat dilihat pada (Tabel 2). 
Tabel 2. Keanekaragaman jenis ikan yang tertangkap di Setiap Stasiun Sungai Tembesi Kecamatan Kecamatan Bathin VIII Kabupaten Sarolangun.

\begin{tabular}{|c|c|c|c|c|c|c|}
\hline \multirow{2}{*}{ No } & \multirow{2}{*}{ Spesies } & \multirow{2}{*}{$\begin{array}{c}\text { Nama } \\
\text { Daerah } \\
\end{array}$} & \multicolumn{3}{|c|}{ Stasiun } & \multirow{2}{*}{$\begin{array}{c}\text { Total } \\
(\mathbf{n})\end{array}$} \\
\hline & & & I & II & III & \\
\hline \multirow[t]{3}{*}{1} & Bagridae & & & & & \\
\hline & Mystus nemurus & Baung & 2 & 3 & 6 & 11 \\
\hline & Bagarius yarelli & Dalum & 6 & 7 & 8 & 21 \\
\hline \multirow[t]{2}{*}{2} & Pangasidae & & & & & \\
\hline & Criptopterus limpok(Blkr) & Lais & 7 & 4 & 6 & 17 \\
\hline \multirow[t]{10}{*}{3} & Cyprinidae & & & & & \\
\hline & Ostechilus hasselti & $\begin{array}{l}\text { Belang } \\
\text { muju }\end{array}$ & 4 & 6 & 5 & 15 \\
\hline & $\begin{array}{l}\text { Schismatorhynchus } \\
\text { heterorhynchus }\end{array}$ & Simancung & 2 & 2 & 7 & 11 \\
\hline & B.schwanel feldi & Lampam & 8 & 5 & 5 & 18 \\
\hline & Osteochilus melanopleura & Semuruk & 2 & 4 & 7 & 13 \\
\hline & Hampala macrolepidota & Kebarau & 1 & 2 & 6 & 9 \\
\hline & Rasbora argyrotaenia & Seluang & 7 & 8 & 8 & 23 \\
\hline & Total Individu & & 39 & 41 & 58 & 138 \\
\hline & Total Spesies & & 9 & 9 & 9 & \\
\hline & Total Genus & & 8 & 8 & 8 & \\
\hline
\end{tabular}

Hasil analisis indeks keanekaragaman menunjukkan bahwa keanekaragaman jenis ikan di Sungai tembesi Kabupaten Sarolangun dalam keadaan relatif sedang. Indeks keanekaragaman tertinggi di jumpai di Stasiun III Dusun Dalam dengan indeks 2.18 dan terendah terdapat pada Stasiun I di Dusun Limbur Tembesi dengan indeks 2.01. Menurut Magurran (1988) menyatakan bahwa keanekaragaman tinggi apabila nilai indeks keanekaragaman $\left(\mathrm{H}^{\prime}\right)>3$; sedang $1<\mathrm{H}^{\prime}<3$ dan rendah jika $\mathrm{H}^{\prime}<1$. Semakin tinggi $\mathrm{H}^{\prime}$ mengindikasikan semakin tinggi jumlah spesies dan kelimpahan relatifnya. Penyebab tingginya indeks keanekaragaman hasil tangkapan di stasiun III diduga karena lingkungan yang masih kondusif dan terjaga.

Berdasarkan hasil penelitian Erika (2018) nilai keanekaragaman ikan di Sungai lenggang berkisar antara $1.870-2.147$ yang termasuk dalam kriteria keanekaragaman sedang yang berarti habitatnya masih dalam keadaan optimal dan masih sesuai untuk peruntukan biota. Indeks keanekaragaman merupakan salah satu indeks ekologi yang biasa digunakan dalam mengevaluasi kondisi suatu ekosistem berdasarkan faktor biologi (organisme).

Indeks keanekaragaman dipengaruhi luas dan kedalaman sungai. Area yang lebih luas sering memiliki variasi habitat yang lebih besar dibandingkan dengan area yang lebih sempit, sehingga semakin 
panjang dan lebar ukuran sungai semakin banyak pula jumlah ikan yang menempatinya (Kottelat et al., 1993).

Adanya hubungan positif antara kekayaan jenis dengan suatu area yang ditempati berhubungan pula dengan keanekaragaman jenis ikan. Keanekaragaman dan kelimpahan ikan juga ditentukan

\section{Indeks Dominasi (D)}

Penentuan jenis ikan yang dominan di masing-masing stasiun penelitian Sungai tembesi oleh karakteristik habitat perairan Kecepatan arus sungai ditentukan perbedaan kemiringan sungai dan keberadaan tumbuhan di sepanjang daerah aliran sungai yang berasosiasi dengan keberadaan satwa penghuninya. Arus yang cepat akan mempengaruhi sebaran jumlah jenis ikan dalam suatu habitat (Yustina, 2001).

Kabupaten Sarolangun dapat dilihat pada (Tabel 3).

Tabel 3. Jumlah Jenis, Individu, Famili, Indeks Dominasi Jenis Ikan di Sungai Tembesi .

\begin{tabular}{lcccc}
\hline \multirow{2}{*}{ Keterangan } & \multicolumn{3}{c}{ Jumlah } & \multirow{2}{*}{ Total } \\
\cline { 2 - 4 } & ST I & ST II & ST III & \\
\hline Jumlah Jenis & 9 & 9 & 9 & $\mathbf{9}$ \\
Jumlah Famili & 3 & 3 & 3 & $\mathbf{3}$ \\
Jumlah Induvidu & 39 & 41 & 58 & $\mathbf{1 3 8}$ \\
Indeks Dominasi Jenis & $\mathbf{0 , 1 4}$ & $\mathbf{0 , 1 3}$ & $\mathbf{0 , 1 1}$ & \\
\hline
\end{tabular}

Berdasarkan Tabel 3 dapat dijelaskan bahwa nilai indeks dominasi pada masing-masing stasiun memiliki nilai yang hampir sama yaitu antara 0.11 sampai dengan 0.14 dan tingginya nilai indeks dominansi ini dikarenakan ada dua spesies ikan dari famili cyrinidae dan bagridae. Dominasi kedua ikan tersebut dikarenakan karateristik ikan tersebut menyukai habitat dengan arus sungai yang lemah dan sedang (Cheng et al., 2004; Rainboth, 1996). Hal tersebut sesuai dengan karakteristik 3 stasiun tersebut yaitu berarus lemah hingga sedang.

Suatu komunitas memiliki keanekaragaman spesies rendah dipengaruhi oleh indeks keseragaman yang rendah dan juga adanya dominasi oleh satu atau sedikit jenis (Efendi et al., 2013). Kekayaan spesies ikan, kelimpahan dan struktur komunitas ikan di sungai tergantung kondisi habitat, meningkatnya volume air di sungai, adanya predator dan kompetisi memperoleh makanan (Simanjuntak, 2012; Jackson et al., 2001). Menurut penelitian Sibuea (2016) nilai indeks dominansi (C) pada setiap stasiun yang ditunjukkan berkisar antara 0.12-0.27. Nilai ini tergolong rendah karena nilainya berada diantara $0-1$. Hal ini membuktikan bahwa ikan ikan pada setiap stasiun tidak ada yang mendominasi secara spesifik atau temporal, namun masih dalam keadaan yang stabil.

Ditambahkan Odum (1996) suatu lingkungan yang stabil 
dicirikan oleh kondisi yang seimbang dan mengandung kehidupan yang beranekaragam tanpa ada suatu spesies yang dominan. Indeks dominansi (D) merupakan indeks yang sering digunakan untuk mengevaluasi keadaan suatu lingkungan perairan

Indeks Keseragaman (E)

Nilai indeks keseragaman tertinggi terdapat pada Stasiun III (Dusun Dalam) dengan $(\mathrm{E}=1.05)$ diikuti stasiun II (Dusun teluk berdasarkan kondisi biologi. Komunitas yang baik mempunyai ciri-ciri penyebaran jenis individu yang hampir merata di setiap perairan. Indikator perairan tercemar pada umumnya di dominansi oleh jenis ikan tertentu ( Krebs, 1972).

Kecimbung $) \quad$ dengan $\quad(\mathrm{E}=1.00)$ kategori sedang serta kategori yang terendah terdapat pada stasiun I $(\mathrm{E}=$ 0.96). Lebih jelas dapat dilihat pada (Tabel 4).

Tabel 4. Jumlah Jenis, Individu, Famili, Indeks keseragaman Jenis Ikan di Sungai Tembesi.

\begin{tabular}{lcccc}
\hline \multirow{2}{*}{ Keterangan } & \multicolumn{3}{c}{ Jumlah } & \multirow{2}{*}{ Total } \\
\cline { 2 - 4 } & ST I & ST II & ST III & \\
\hline Jumlah Jenis & 9 & 9 & 9 & $\mathbf{9}$ \\
Jumlah Famili & 3 & 3 & 3 & $\mathbf{3}$ \\
Jumlah Induvidu & 39 & 41 & 58 & $\mathbf{1 3 8}$ \\
Indeks Keseragaman & $\mathbf{0 , 9 6}$ & $\mathbf{1}$ & $\mathbf{1 , 0 5}$ & \\
\hline
\end{tabular}

Nilai indeks keseragaman yang rendah memperlihatkan bahwa jenis-jenis ikan yang tertangkap di setiap stasiun menunjukan bahwa ikan tidak terdistribusi secara merata hal ini terjadi karena perbedaan kualitas air (Kawaroe et al, 2001). Rendahnya nilai indeks keseragaman pada ketiga stasiun tersebut juga diduga karena kondisi lingkungan yang kurang menguntungkan dan juga adanya dominasi dari spesies tertentu (Asriyana et al., 2009).

Kriteria nilai keseragaman, jika E mendekati 0 maka kemerataan antara spesies rendah, dan jika E mendekatil maka kemerataan antara spesies relatif merata atau jumlah individu masing-masing spesies relatif sama (Jukri \& Erniyati, 2013). Menurut Sibuea (2016) nilai indeks keseragaman (E) pada setiap stasiun berkisar antara 0.61-0.89. Nilai ini menyatakan bahwa ikan memiliki sebaran yang luas di setiap lokasi penelitian.

Keseragaman (E) digunakan untuk mengetahui kemerataan proporsi masing-masing jenis ikan di suatu ekosistem. Krebs (1972) menyatakan bahwa semakin kecil nilai (E) maka semakin kecil pula keseragaman suatu populasi dan penyebaran individu yang mendominasi populasi sedangkan bila nilainya semakin besar maka akan semakin besar pula keseragaman suatu populasi dimana jenis dan jumlah individu tiap jenisnya merata atau seragam. 
Kepadatan Populasi, Kepadatan Relatif dan Frekuensi Kehadiran

Hasil pengamatan menunjukan kepadatan Populasi (KP) tertinggi ditemukan pada jenis ikan: seluang (Rasbora argyrotaenia) sebesar $0.0038 \quad$ (individu) $/ \mathrm{m}^{2}, \quad$ dalum (Makrones mikrocanthus) 0.0035 (individu $/ \mathrm{m}^{2}$ ), lampam (Puntius schwanefeldi) sebesar 0.0030 (individu $/ \mathrm{m}^{2}$ ), lais (Criptopterus limpok) sebesar $\quad 0,0028$ (individu $/ \mathrm{m}^{2}$ ) dan belang muju (Ostechilus hasselti) sebesar 0.0025 (individu $/ \mathrm{m}^{2}$ ). Hal ini di duga karena kualitas air yang baik serta jenis-jenis ikan ini memiliki kemampuan dalam mencari makanan.

Kepadatan Relatif (KR) tertinggi terdapat pada ikan seluang (Rasbora argyrotaenia) sebesar $16,666 \%$. Sedangkan Kepadatan Relatif (KR) yang rendah di temukan terdapat pada ikan kebarau (Hampala macrolepidota), $0.0015 \%$. Sedangkan untuk Frekuensi Kehadiran (FK) tertinggi ditemukan pada ikan seluang (Rasbora argyrotaenia) sebesar $0.0038 \quad$ (individu) $/ \mathrm{m}^{2}$, dalum (Makrones mikrocanthus) 0.0035 (individu $/ \mathrm{m}^{2}$ ), lampam (Puntius schwanefeldi) sebesar 0.0030 (individu $/ \mathrm{m}^{2}$ ), lais (Criptopterus limpok) sebesar $\quad 0.0028$ (individu $/ \mathrm{m}^{2}$ ) dan belang muju (Ostechilus hasselti) sebesar 0.0025 (individu $/ \mathrm{m}^{2}$ ) dengan nilai $\mathrm{FK}$ antara $66.66 \%$ sampai dengan $100.00 \%$. Sedangkan Frekuensi Kehadiran (FK) terendah ditemukan pada ikan kebarau (Hampala macrolepidota) dengan persentase $50.00 \%$. Hasil perhitungan Kepadatan Populasi, Kepadatan Relatif dan Frekuensi Kehadiran lebih jelas dapat dilihat pada (Tabel 5).

Tabel 5. Hasil Perhitungan Kepadatan Populasi, Kepadatan Relatif, dan Frekuensi Kehadiran.

\begin{tabular}{lllrr}
\hline No & \multicolumn{1}{c}{ Jenis Ikan } & KP & \multicolumn{1}{c}{ KR } & \multicolumn{1}{c}{ FK } \\
\hline 1 & Mystus nemurus & 0,0018 & 79.701 & 66,66 \\
2 & Bagarius yarelli & 0.0035 & 15,217 & 100.00 \\
3 & Criptopterus limpok(Blkr) & 0,0028 & 12,318 & 75 \\
4 & Ostechilus hasselti & 0.0025 & 10,869 & 66,66 \\
5 & Schismatorhynchus heterorhynchus & 0,0018 & 79.701 & 66,66 \\
6 & B.schwanefeldi & 0,003 & 13,043 & 100.00 \\
7 & Osteochilus melanopleura & 0,0021 & 9,42 & 75 \\
8 & Hampala macrolepidota & 0,0015 & 6,521 & 50.00 \\
9 & Rasbora argyrotaenia & 0,0038 & 16,666 & 100.00 \\
\hline \multicolumn{2}{c}{ Total } & $\mathbf{0 . 0 2 2 8}$ & & $\mathbf{7 7 , 7 7 \%}$ \\
\cline { 2 - 5 }
\end{tabular}

Berdasarkan Tabel 5 Kriteria penilaian keanekaragaman jenis Shannon-Wienner, maka Frekuensi Kehadiran (FK\%) Jenis Ikan di Sungai tembesi Kabupaten Sarolangun Propinsi Jambi dapat dikatakan dengan kehadiran sedang yaitu $77.77 \%$. Menurut Erika (2018) nilai frekuensi keterdapatan $100 \%$, menandakan bahwa spesies tersebut ditemukan pada setiap stasiun penelitian dan pada tiap pengambilan data. Frekuensi keterdapatan berkaitan erat dengan 
wilayah penyebaran, artinya semakin besar nilai keterdapatan berarti semakin luas wilayah penyebarannya, selain itu juga

\section{KESIMPULAN DAN SARAN Kesimpulan}

Hasil dari penelitian ini dapat disimpulkan bahwa jenis ikan yang terdapat di Sungai tembesi terdiri dari jenis ikan baung (Mystus nemurus), dalum (Bagarius yarelli), lais (Criptopterus limpok) belang muju (Ostechilus haselti), simancung (Schismatorhichus heterorhynchus), lampam (B.schwanenfeldi), semuruk (Osteochilus melanopleura), kebarau (Hampala macrolepidato), seluang (Rasbora argyrotaenia). Indeks keanekaragaman tertinggi di jumpai di Stasiun III Dusun Dalam dengan indeks 2.18 dan terendah terdapat pada Stasiun I di Dusun Limbur Tembesi dengan indeks 2.01. Nilai Indeks Dominansi (D) tertinggi pada stasiun 1 yaitu 0.14 dan terendah terdapat pada stasiun III dengan nilai 0.11 . Nilai Indeks Keseragaman (E) tertinggi terdapat pada stasiun III dengan nilai 1.05 dan terendah pada stasiun I 0.96 . Kepadatan Populasi (KP) tertinggi

\section{DAFTAR PUSTAKA}

Asriyana, R. M., Sukimin, S., Lumban Batu, D. T. F., \& Kartamihardja, E. S. (2009). Keanekaragaman ikan di perairan Teluk Kendari, Sulawesi Tenggara. Jurnal Iktiologi Indonesia, 9(2), 97112.

Brower, J. E., Zar, J. H., \& Von Ende, C. N. (1990). Field and laboratory methods for general ecology 3rd ed. Wm. spesies yang memiliki frekuensi keterdapatan tinggi umumnya adalah spesies yang memiliki adaptasi tinggi.

ditemukan pada jenis ikan seluang (Rasbora argyrotaenia), dalum (Bagarius yarelli), lampam (B.schwanenfeldi), lais (Criptopterus limpok) dan belang muju (Ostechilus haselti). Kepadatan Relatif (KR) tertinggi terdapat pada ikan seluang (Rasbora argyrotaenia) dan terendah pada ikan kebarau (Hampala macrolepidato). Frekuensi Kehadiran (FK\%) jenis ikan di Sungai tembesi Kabupaten Sarolangun Propinsi Jambi dapat dikatakan dengan kehadiran sedang yaitu $77.77 \%$.

\section{Saran}

Sebagai saran diharapkan ada penelitian lanjutan dan lokasi sampling ditambah agar sampel ikan didapat lebih banyak. Penggunaan jenis alat tangkap juga dioptimalkan dengan pengulangan lebih banyak di setiap stasiun.

Efendi, W.W., Fitroh N.P.H., Zulaikah N. (2013). Studi Inventarisasi Keanekaragaman Tumbuhan Paku di Kawasan Wisata Coban Rondo Kabupaten Malang. Cogito Ergo Sum. 2(3):173-188.

Erika, R., Kurniawan, K., \& Umroh, U. (2018). Keanekaragaman Ikan di Perairan Sungai Linggang, Kabupaten Belitung Timur. Akuatik: Jurnal Sumberdaya Perairan, 12(2), 17-25. 
Fithra, R. Y., \& Siregar, Y. I. (2010). Keanekaragaman ikan Sungai Kampar Inventarisasi dari Sungai Kampar Kanan. Jurnal Ilmu Lingkungan, 4(02).

Jackson, D.A, Peres-Neto PR, Olden JD. (2001). What controls who is where in freshwater fish communities- the roles of biotic, abiotic, and spatial factors. Canadian Journal of Fisheries and Aquatic Sciences, 58:157-200.

Jukri, M., \& Emiyati, K. S. (2013). Keanekragaman Jenis Ikan di Sungai Lamunde Kecamatan Watubangga Kolaka Provinsi Sulawesi Tenggara. Jurnal Mina Laut Indonesia, 1(01).

Kawaroe, M., Bengen, D. G., Eidman, M., \& Boer, M. (2001). Kontribusi ekosistem mangrove terhadap struktur komunitas ikan di Pantai Utara Kabupaten Subang, Jawa Barat. Pesisir dan lautan, 3(3), 12-25.

Kottelat, M; A. J. Whitten; S. N. Kartikasari \& S. Wirjoatmojo. (1993). Freshwater of Western Indonesia and Sulawesi. London: Periplus Edition.

Krebs, C. J. (1972). Ecologythe experimental analysis of distribution and abundance (No. $\quad 574.5028$ K7).

Magurran, A. E. (1988). Ecological diversity and its measurement. Princeton university press.

Muslih, K., Adiwilaga, E. M., \& Adiwibowo, S. (2016). Pengaruh penambangan timah terhadap keanekaragaman ikan sungai dan kearifan lokal masyarakat di Kabupaten Bangka. LIMNOTEK-
Perairan Darat Tropis di Indonesia, 21(1).

Novri, F. (2006). Analisis hasil tangkapan dan pola musim penangkapan ikan tenggiri (Scomberomorus spp.) di perairan Laut Jawa bagian barat berdasarkan hasil tangkapan yang didaratkan di PPI Muara Angke, Jakarta Utara. Skripsi (Tidak Dipublikasikan) Departemen Pemanfaatan Sumberdaya Perikanan Fakultas Ilmu Kelautan dan Perikanan Institut Pertanian Bogor, hal, 103.

Odum, E P. (1996). Dasar-Dasar Ekologi : edisi ketiga. Yogyakarta :Gadja Mada University Press.

Preniti, R., Syafrialdi, S., \& Djunaidi, D. (2019). Studi Keanekaragaman Ikan Yang Tertangkap Menggunakan Atribut Rumpon Berbeda di Sungai Mentenang Kabupaten Merangin. SEMAH Jurnal Pengelolaan Sumberdaya Perairan, 3(1).

Rainboth, W. J. (1996). The taxonomy, systematics, and zoogeography of Hypsibarbus, a new genus of large barbs (Pisces, Cyprinidae) from the rivers of Southeastern Asia (Vol. 129). Univ of California Press.

Sibuea, A. D., Mulya, M. B., \& Djayus, Y. (2016). Keanekaragaman Jenis Ikan dan Keterkaitannya Parameter Fisika Kimia Perairan Estuari Suaka Margasatwa Karang Gading Kabupaten Deli Serdang Sumatera Utara. AQUACOASTMARINE, 14(4), 1-10. 
Simanjuntak, C. P. (2017).

Keragaman dan struktur kumpulan ikan di anak sungaianak sungai Sopokomil, Dairi, Sumatera Utara [Fish diversity and assemblage structure in tributaries of Sopokomil River, Dairi, North Sumatra]. Jurnal Iktiologi Indonesia, 12(2), 155-172.

Sudrajat, A, Darti Satiyani, Sudarto, Ketut Sugama dan Murniyati, (2009). Inventarisasi Keragaman Ikan lokal Air Tawar Propinsi Jambi, Dinas Kelautan dan Perikanan Propinsi Jambi, Jambi, Cetakan ke 2, 81 pp.

Yustina. 2001. Keanekaragaman Jenis Ikan di Sepanjang Perairan Sungai Rangau, Riau, Sumatera. Tesis, Program Pasca Sarjana Jurusan Biologi, Institut Teknologi Bandung, Bandung (tidak diterbitkan). 